Effects of different row spacing on yield and yield components of some flax (Linum usitatissimum L.) varieties

\author{
Ayşe ÇOBAN ${ }^{1}$, Cenk Burak ŞAHIN ${ }^{1}$, Necmi IŞLER *1 \\ ORCID: 0000-0002-5092-9446; 0000-0001-6270-8184; 0000-0001-5877-7830
}

${ }^{1}$ Hatay Mustafa Kemal Üniversitesi Ziraat Fakültesi Tarla Bitkileri Bölümü, 31000 Antakya-Hatay, Turkey

\begin{abstract}
This study was conducted to determine the effects of row spacing on yield and important agronomic characteristics of linen at the experimental area of Hatay Mustafa Kemal University in 2019-20 growing season. Linen varieties Beyaz Gelin and Kara Kiz were used as plant materials. The study was established in split-plot design with three replications. Row spacing $(15,30,45,60 \mathrm{~cm})$ were placed in main plots and varieties (Beyaz Gelin, Kara Kiz) in sub-plots. In this study, plant height $(\mathrm{cm})$, technical stem length $(\mathrm{cm})$, number of fruit branches per plant, number of side branches per plant, seed yield $\left(\mathrm{kg} \mathrm{da}^{-1}\right)$, the number of capsules in the plant, the number of seeds in the capsule, thousand grain weight $(\mathrm{g})$, oil and protein ratio $(\%)$ were investigated. According to the results, the highest seed yield was obtained from $15 \mathrm{~cm}$ row spacing $\left(218.73 \mathrm{~kg} \mathrm{da}^{-1}\right)$ and Kara Kiz variety $\left(154.15 \mathrm{~kg} \mathrm{da}^{-1}\right)$. The average oil and protein ratio were $36.11 \%$ and 20.01 , respectively. It was determined that the seed yield, plant height and technical stem length increased when the row spacing decreased. It is better to prefer Kara Kiz variety and $15 \mathrm{~cm}$ row spacing for the highest seed yield.
\end{abstract}

Keywords: Linum usitatissimum L., row spacing, linen

\title{
Bazı keten çeşitlerinde farklı sıra aralıklarının verim ve verim unsurları üzerine etkisi
}

\section{Özet}

$\mathrm{Bu}$ çalışma, Hatay koşullarında farklı sıra aralığında yetiştirilen keten bitkisinin verim ve bazı tarımsal özelliklere etkisini belirlemek amacıyla 2019-20 yılında Hatay Mustafa Kemal Üniversitesi Araştırma ve Deneme alanında yürütülmüştür. Araştırmada, Beyaz Gelin ve Kara Kız keten çeşitleri bitki materyali olarak kullanılmıştır. Bölünmüş parseller deneme desenine göre 3 yinelemeli olarak kurulup yürütülen bu çalışmada sıra aralıkları (15, 30, 45, $60 \mathrm{~cm}$ ) ana parsellere, çeşitler (Beyaz Gelin, Kara Kız) alt parsellere yerleştirilmiştir. Çalışmada; bitki boyu (cm), teknik sap uzunluğu $(\mathrm{cm})$, bitki başına meyveli dal sayısı (adet), bitki başına yan dal sayısı (adet), tohum verimi (kg da${ }^{1}$ ), bitkideki kapsül sayısı (adet), kapsüldeki tohum sayısı (adet), bin tane ağırlığı (g), yağ ve protein oranı (\%) gibi özellikler incelenmiştir. Çalışma sonucunda elde edilen verilere göre, dekara en yüksek tohum verimi $15 \mathrm{~cm}$ sıra aralığından $\left(218.73 \mathrm{~kg} \mathrm{da}^{-1}\right)$ ve Kara Kız çeşidinden $\left(154.15 \mathrm{~kg} \mathrm{da}^{-1}\right)$ elde edilmiştir. Çalışmadaki ortalama yağ oranı \%36.11 ve protein oranı \%20.01 olmuştur. Araştırma sonuçlarına göre, sıra aralığ1 azaldıkça tohum veriminin, bitki boyunun ve teknik sap uzunluğunun arttığı belirlenmiştir. En yüksek tohum verimi için Kara Kız çeşidinin ve $15 \mathrm{~cm}$ sıra aralı̆̆ının tercih edilmesi önerilebilir.

Anahtar kelimeler: Linum usitatissimum L., sira aras1, keten

\section{Giriș}

Linaceae familyasından olan keten (Linum usitatissimum L.) bitkisi lif ve yağ tipi olmak üzere iki değişik forma sahip bir endüstri bitkisidir. Kültüre alındığı ilk dönemlerde lif amaçlı kullanılan bitki, zamanla farklı alanlarda

\footnotetext{
* Corresponding author / Haberleşmeden sorumlu yazar: Tel.: +905424967689; Fax.: +905424967689; E-mail: nisler@mku.edu.tr

(C) Copyright 2021 by Biological Diversity and Conservation Geliş tarihi: 05.03.2021; Yayın tarihi: 15.08.2021 BioDiCon. 962-0321
} 
da değerlendirilmiştir. Başta boya sanayi olmak üzere sabun, cam macunu, matbaa mürekkebi yapımlarında kullanılmaktadır [1]. Ketenin 200 türü bulunmasına rağmen kültürü yapılan tek tür Linum usitatissimum L.'dir [2].

Lif tipi ketenler çoğunlukla nispi nemi yüksek olan kıyı bölgelerde yetiştirilirken, yağ tipi ketenler ise daha kurak ve sıcak alanlarda yetiştirilmektedir. Yağ tipi keten tohumları \%30-45 oranında yağ içermektedir. Doymamış yağ asidi oranı yüksek olup yaklaşık \%65 oranında linolenik asit (Omega 3) bulunmaktadır [3, 4]. Bu oranın yüksek olması nedeniyle aroma ve koku yönünden olumsuz etki bırakması yemeklik yağ olarak tüketimini sınırlandırmış, ancak, çabuk kuruma özelliği kazandırması sebebiyle de farklı sanayi alanlarında değerlendirilmesini sağlamıştır [2].

2019 yılı verilerine göre, Dünya'da yaklaşık 3.2 milyon ha alanda yaklaşı 3.1 milyon ton keten tohumu üretimi olmuştur. Ortalama verim $95 \mathrm{~kg} \mathrm{da}^{-1}$ olarak tespit edilmiştir. Üretimin neredeyse tamamı Asya (\%49.6), Avrupa (\%25.4) ve Amerika (\%21.7) kıtalarından elde edilmiştir. En önemli üretici ülkeler sırasıyla Kazakistan (1 milyon ton), Rusya (658 bin ton), Kanada (486 bin ton), Çin (340 bin ton) ve ABD (162 bin ton)'dir [5]. Türkiye'de ise 2020 y1lında hasat edilen 83 da alanda 4 ton keten üretimi gerçekleşmiştir. Bu ekim alanını Yozgat (46 da), Afyonkarahisar (25 da) ve Sinop (12 da) illeri oluşturmuş, üretim miktarı ise Afyonkarahisar (2 ton) ve Yozgat (2 ton) illerinden elde edilmiştir. Türkiye'de ortalama verim $48 \mathrm{~kg} \mathrm{da}^{-1}$ iken Afyonkarahisar'da $80 \mathrm{~kg} \mathrm{da}^{-1}$ ve Yozgat'ta $43 \mathrm{~kg} \mathrm{da}^{-1}$ olmuştur [6].

Keten, Türkiye'nin yüksek rakımlı yöreleri dışında neredeyse her yerde yetişme imkânı bulunan ve çeşitli kullanım alanlarıyla ön plana çıkan bir bitkidir. Özellikle hem lif hem de yağ için yetiştirilebilmesi, toprak isteği bakımından çok seçici olmaması ve toprağı yormaması, ekim nöbeti içerisinde yer alabilmesi gibi olumlu yönleriyle mevcut türlere alternatif olabilecek bir yağlı tohum kaynağıdır [7, 8].

$\mathrm{Bu}$ çalışmayla, Hatay ekolojik koşullarında farklı sıra aralıklarında yetiştirilen keten çeşitlerinin performansının ve yetiştirilme olanağının belirlenmesi amaçlanmıştır.

\section{Materyal ve yöntem}

\subsection{Materyal}

Trakya Tarımsal Araştırma Enstitüsü’nden temin edilen Kara Kız ve Beyaz Gelin keten çeşitleri bitki materyali olarak kullanılmıştır. Çeşitlerin her ikisi de yazlık karakterli ve kahverengi tohum rengine sahiptir. Çiçek rengi olarak ise Kara Kız açık mavi ve Beyaz Gelin beyaz renklidir. Killi-tınlı yapıdaki deneme arazisinin kireç içeriği yüksek olup organik madde yönünden fakirdir (Tablo 1).

Tablo 1. Denemenin yürütüldüğü alanın toprak $(0-40 \mathrm{~cm})$ analiz sonucu

\begin{tabular}{cccccc}
\hline Saturasyon & $\mathrm{pH}$ & O.M. $(\%)$ & Kireç (\%) & $\mathrm{P}\left(\mathrm{kg} \mathrm{da}^{-1}\right)$ & $\mathrm{K}\left(\mathrm{kg} \mathrm{da}^{-1}\right)$ \\
\hline Killi-tınlı & 7.63 & 1.58 & 21.66 & 19.7 & 104.5 \\
\hline O.M.: Organik Madde; P: Yarayışlı fosfor; K: Yarayışlı potasyum & & &
\end{tabular}

Araştırmanın yürütüldüğü dönem ile uzun yıllar ortalaması arasında ortalama sıcaklık ve nispi nem benzerdir. Toplam yağış miktarı ise uzun yıllar ortalamasından yaklaşık $60 \mathrm{~mm}$ daha fazladır (Tablo 2).

Tablo 2. Denemenin yürütüldüğü alanda yetiştirme sezonuna ait iklim verileri*

\begin{tabular}{lcccccc}
\hline \multirow{2}{*}{ Aylar } & \multicolumn{2}{c}{ Yağış $(\mathrm{mm})$} & \multicolumn{2}{c}{ Sicaklık $\left({ }^{\circ} \mathrm{C}\right)$} & \multicolumn{2}{c}{ Nispi Nem $(\%)$} \\
\cline { 2 - 7 } & UYO & $2019-20$ & UYO & $2019-20$ & UYO & $2019-20$ \\
\hline Kasım & 34.55 & 45.40 & 13.6 & 14.8 & 66.5 & 70.0 \\
Aralık & 65.54 & 181.00 & 8.6 & 10.0 & 82.0 & 95.8 \\
Ocak & 96.20 & 63.60 & 7.5 & 9.0 & 84.9 & 87.8 \\
Şubat & 58.50 & 31.60 & 9.7 & 9.6 & 76.0 & 84.9 \\
Mart & 54.56 & 49.40 & 13.2 & 14.9 & 70.4 & 82.1 \\
Nisan & 39.68 & 38.20 & 17.5 & 18.1 & 64.8 & 76.0 \\
Mayıs & 15.03 & 13.80 & 22.0 & 23.2 & 60.0 & 63.4 \\
\hline T / O & 364.06 & 423.00 & 13.2 & 14.2 & 72.1 & 80.0 \\
\hline
\end{tabular}

* Hatay Meteoroloji Müdürlüğü. UYO: Uzun Y1llar Ortalaması. T / O: Toplam veya ortalama.

\subsection{Yöntem}

Deneme, Hatay Mustafa Kemal Üniversitesi Ziraat Fakültesi Araştırma ve Uygulama Arazisinde 2019-2020 ekim sezonunda yürütülmüştür. Bölünmüş parseller deneme desenine göre 3 yinelemeli olarak kurulan denemede sıra aralıkları $(15,30,45,60 \mathrm{~cm})$ ana parsellere ve çeşitler (Beyaz Gelin, Kara Kız) alt parsellere yerleştirilmiştir. Her parsel 5 m uzunluğundaki 4 sıradan oluşturulmuş ve 21.11.2019 tarihinde elle ekim yapılmıştır. Ekimle birlikte dekara $10 \mathrm{~kg}$ saf N-P-K hesabıyla 15-15-15 kompoze gübresinden verilmiş ve yağmurlama sulama ile ilk sulama gerçekleştirilmiştir. Yetiştirme dönemi boyunca gereken bakım işlemleri ve kültürel uygulamalar yapılmıştır. Deneme süresince gerekli 
gözlemler alınmış ve 03.06.2020 tarihinde hasat edilmiştir. Gözlemler her parselden rastgele seçilen ve parseli temsil eden 10 bitkiden alınmış, kenar tesirleri atıldıktan sonra kalan kısım hasat edilerek tohum verimi hesaplanmıştır.

Elde edilen veriler bölünmüsş parseller deneme desenine göre SPSS 22 paket programı yardımıyla varyans analizine tabi tutulmuş, ortalamaların karşılaştırılmasında Duncan çoklu karşılaştırma testi kullanılmıştır.

\section{Bulgular}

4'te verilmiştir.

Yapılan varyans analizi sonucunda elde edilen ortalama değerler ile Duncan gruplarına ait bilgiler Tablo 3 ve

Bitki boyuna farklı sıra aralıklarının etkisi istatistiki olarak önemli $(\mathrm{p}<0.01)$ bulunurken, çeşit ve sıra aralı̆̆ $\mathrm{x}$ çeşit interaksiyonun etkisi önemsiz bulunmuştur (Tablo 3). Bitki boyu değerleri sıra aralıklarında 63.70-79.21 cm arasında değişirken, en yüksek değer $79.21 \mathrm{~cm}$ ile $30 \mathrm{~cm}$ sıra aralı̆̆ından elde edilmiştir. Çeşitlerde ise bitki boyu Beyaz Gelin çeşidinde $73.11 \mathrm{~cm}$ ve Kara Kız çeşidinde $71.84 \mathrm{~cm}$ olmuştur. Bitki boyu ortalamasının $72.47 \mathrm{~cm}$ olduğu tespit edilmiştir. Bitki boyunun yüksek olması özellikle lif tipi ketenlerde arzulanan bir özelliktir. Ancak, yağlık ketenlerde de verimi doğrudan etkileyen parametrelerden biri olduğu bildirilmiştir [1, 4, 7, 9]. Araştırma sonuçlarımız, [7, 10, 11, 12] sonuçlarıyla paralellik gösterirken, $[1,4,8,13]$ sonuçlarından yüksek bulunmuştur. Araştırmalar arasındaki bu farklılığın toprak ve iklim koşulları ile çeşidin genetik yapısından kaynaklandığı söylenebilir.

Teknik sap uzunluğuna farklı sıra aralıklarının, çeşitlerin ve sıra aralı̆̆ x çeşit interaksiyonunun etkisi istatistiki olarak önemli $(\mathrm{p}<0.01)$ bulunmuştur (Tablo 3). Teknik sap uzunluğu değerleri sıra aralıklarında 43.03-56.57 $\mathrm{cm}$ arasında değişisken, en yüksek değerler aynı istatistiki grupta yer alan $15 \mathrm{~cm}(56.57 \mathrm{~cm})$ ve $30 \mathrm{~cm}(55.02 \mathrm{~cm})$ sira aralıklarından elde edilmiştir. Farklı sıra aralığının artmasıyla teknik sap uzunluğunda azalmalar meydana gelmiştir. Çeşitlerde ise teknik sap uzunluğu Beyaz Gelin çeşidinde $52.76 \mathrm{~cm}$ ve Kara Kız çeşidinde $50.24 \mathrm{~cm}$ olmuştur. Teknik sap uzunluğu ortalamasının $51.50 \mathrm{~cm}$ olduğu tespit edilmiştir. Teknik sap uzunluğunun yağ tipi ketenlerde fazla önem arz etmediği, özellikle lif tipi ketenler için önemli ve en az $60 \mathrm{~cm}$ uzunluk ile 1-2 mm kalınlıkta olmasının arzu edilen bir özellik olduğu bildirilmiştir [8].

Bitki başına meyveli dal sayısına farklı sıra aralıklarının, çeşitlerin ve sıra aralığı x çeşit interaksiyonunun etkisi istatistiki olarak önemsiz $(\mathrm{p}>0.05)$ bulunmuştur (Tablo 3). Bitki başına meyveli dal sayısı değerleri sıra aralıklarında 12.02-14.43 adet arasında değişirken, en yüksek değer 14.43 adet ile $45 \mathrm{~cm}$ ve 14.12 adet ile $30 \mathrm{~cm}$ sıra aralığından elde edilmiştir. Maksimum meyveli dal sayısına $30-45 \mathrm{~cm}$ sıra aralıklarından ulaşılmış, sıra aralı̆̆ $60 \mathrm{~cm}$ 'ye çıtığında ve $15 \mathrm{~cm}$ 'ye düştüğünde meyveli dal sayısında azalışlar meydana gelmiştir. Çeşitlerde ise bitki başına meyveli dal sayısı Kara Kız çeşidinde 13.43 adet ve Beyaz Gelin çeşidinde 13.23 adet olmuştur. Bitki başına meyveli dal sayısı ortalamasının 13.33 adet olduğu tespit edilmiştir. Bitki sıklığı arttıkça meyveli dal sayısının düştüğü bildirilmiştir [12].

Tablo 3. Bitki boyu, teknik sap uzunluğu, meyveli dal sayısı, yan dal sayısı ve tohum verimi özelliklerinin ortalama değerleri

\begin{tabular}{|c|c|c|c|c|c|}
\hline & Bitki Boyu $(\mathrm{cm})$ & $\begin{array}{c}\text { Teknik Sap } \\
\text { Uzunluğu }(\mathrm{cm})\end{array}$ & $\begin{array}{c}\text { Meyveli Dal } \\
\text { Sayıs1 (adet bitki- } \\
1 \text { ) }\end{array}$ & $\begin{array}{c}\text { Yan Dal Sayıs1 } \\
\left(\text { adet bitki }{ }^{-1}\right)\end{array}$ & $\begin{array}{l}\text { Tohum Verimi (kg } \\
\left.\qquad \mathrm{da}^{-1}\right)\end{array}$ \\
\hline \multicolumn{6}{|l|}{ Stra Aralı̆̆ } \\
\hline $15 \mathrm{~cm}$ & $73.68 \pm 3.22 \mathrm{~b}$ & $56.57 \pm 3.04 \mathrm{a}$ & $12.02 \pm 1.28$ & $4.88 \pm 0.98 \mathrm{a}$ & $218.73 \pm 20.22 \mathrm{a}$ \\
\hline $30 \mathrm{~cm}$ & $79.21 \pm 2.79 \mathrm{a}$ & $55.02 \pm 3.30 \mathrm{a}$ & $14.12 \pm 1.50$ & $3.42 \pm 0.70 \mathrm{~b}$ & $168.20 \pm 26.91 \mathrm{~b}$ \\
\hline $45 \mathrm{~cm}$ & $73.30 \pm 1.18 \mathrm{~b}$ & $51.38 \pm 2.20 \mathrm{~b}$ & $14.43 \pm 1.74$ & $3.78 \pm 0.80 \mathrm{ab}$ & $137.88 \pm 6.18 \mathrm{c}$ \\
\hline $60 \mathrm{~cm}$ & $63.70 \pm 3.06 \mathrm{c}$ & $43.03 \pm 2.56 \mathrm{c}$ & $12.73 \pm 1.22$ & $3.22 \pm 0.17 \mathrm{~b}$ & $69.22 \pm 6.93 \mathrm{~d}$ \\
\hline \multicolumn{6}{|l|}{ Çeşit } \\
\hline KK & $71.84 \pm 6.32$ & $50.24 \pm 6.76 \mathrm{~B}$ & $13.43 \pm 2.03$ & $3.84 \pm 1.14$ & $154.15 \pm 63.80 \mathrm{~A}$ \\
\hline BG & $73.11 \pm 6.34$ & $52.76 \pm 5.00 \mathrm{~A}$ & $13.23 \pm 1.35$ & $3.81 \pm 0.76$ & $142.86 \pm 52.98 \mathrm{~B}$ \\
\hline Ortalama & $72.47 \pm 6.23$ & $51.50 \pm 5.96$ & $13.33 \pm 1.69$ & $3.83 \pm 0.94$ & $148.50 \pm 57.64$ \\
\hline Sura Aralığ1 & $* *$ & $* *$ & öd & $* *$ & $* *$ \\
\hline Çeşit & öd & $* *$ & öd & öd & * \\
\hline $\mathrm{S} \times \mathrm{C}$ & öd & $* *$ & öd & öd & öd \\
\hline C.V. (\%) & 2.82 & 3.39 & 9.22 & 22.54 & 7.47 \\
\hline
\end{tabular}

$* \mathrm{p}<0.05,{ }^{* *} \mathrm{p}<0.01$ düzeyinde önemlidir. A, B harfleri çeşitler arasındaki ve a, b, c, d harfleri ise sıra aralı̆ı arasındaki farkı göstermektedir. öd: Önemli değil. CV: Varyasyon katsayısı. KK: Kara Kız, BG: Beyaz Gelin.

Yan dal sayısına farklı sıra aralıklarının etkisi istatistiki olarak önemli $(\mathrm{p}<0.01)$ bulunurken, çeşit ve sıra aralığ $\mathrm{x}$ çeşit interaksiyonun etkisi önemsiz bulunmuştur (Tablo 3). Yan dal sayısı değerleri sıra aralıklarında 3.22-4.88

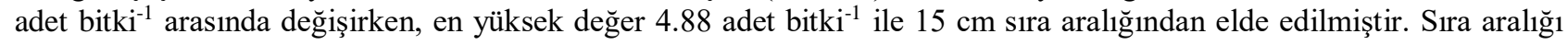
daraldıkça bitkilerde daha fazla yan dal oluştuğu görülmüştür. Çeşitlerde ise yan dal sayısı Kara Kız çeşidinde 3.84 adet 
bitki $^{-1}$ ve Beyaz Gelin çeşidinde 3.81 adet bitki ${ }^{-1}$ olmuştur. Yan dal sayısı ortalamasının 3.83 adet bitki ${ }^{-1}$ olduğu tespit edilmiştir. Yağ tipi ketenlerde yan dal sayısının tohum verimini doğrudan etkilediği, dal sayısının ve dağılımının bitki sıklığına bağlı olduğu bildirilmiştir $[1,4,7,9]$.

Tohum verimine farklı sıra aralıklarının ve çeşitlerin etkisi istatistiki olarak önemli $(\mathrm{p}<0.05)$ bulunurken, sıra aralığ1 x çeşit interaksiyonun etkisi önemsiz bulunmuştur (Tablo 3). Tohum verimi değerleri sıra aralıklarında 69.22-218.73 $\mathrm{kg} \mathrm{da}^{-1}$ arasında değişirken, en yüksek değer $218.73 \mathrm{~kg} \mathrm{da}^{-1}$ ile $15 \mathrm{~cm}$ sıra aralığından elde edilmiştir.

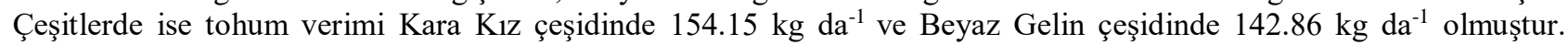
Tohum verimi ortalamasının $148.50 \mathrm{~kg} \mathrm{da}^{-1}$ olduğu tespit edilmiştir. Araştırma sonuçlarımız çeşitli araştırmalarla paralellik göstermiştir [1, 4, 8, 11, 13, 14].

Bitkideki kapsül sayısına farklı sıra aralıklarının etkisi istatistiki olarak önemli $(\mathrm{p}<0.01)$ bulunurken, çeşit ve sıra aralığı x çeşit interaksiyonun etkisi önemsiz bulunmuştur (Tablo 4). Bitkideki kapsül sayısı değerleri sıra aralıklarında 16.63-41.85 adet arasında değişirken, en yüksek değerler aynı istatistiki grupta yer alan 30,45 ve $60 \mathrm{~cm}$ sıra aralıklarından elde edilmiştir. Sıra aralığı $30 \mathrm{~cm}$ 'nin altına düştüğünde oluşan kapsül sayısının neredeyse yarı yarıya azaldığı görülmüştür. Çeşitlerde ise bitkideki kapsül sayısı Beyaz Gelin çeşidinde 33.58 adet ve Kara Kız çeşidinde 31.93 adet olmuştur. Bitkideki kapsül sayısı ortalamasının 32.76 adet olduğu tespit edilmiştir. Kapsül sayısının sık ekimde daha az, seyrek ekimde ise daha fazla olduğu bildirilmiştir [4].

Kapsüldeki tohum sayısına farklı sıra aralıklarının etkisi istatistiki olarak önemli $(\mathrm{p}<0.05)$ bulunurken, çeşit ve sıra aralığı x çeşit interaksiyonun etkisi önemsiz bulunmuştur (Tablo 4). Kapsüldeki tohum sayısı değerleri sıra aralıklarında 5.98-8.33 adet arasında değişirken, en yüksek değer 8.33 adet ile $45 \mathrm{~cm}$ sıra aralığından elde edilmiştir. Bitkideki kapsül sayısına benzer şekilde en düşük değer $15 \mathrm{~cm}$ sıra aralığından alınmıştır. Çeşitlerde ise kapsüldeki tohum sayısı Kara Kız çeşidinde 7.19 adet ve Beyaz Gelin çeşidinde 6.97 adet olmuştur. Kapsüldeki tohum sayıs1 ortalamasının 7.08 adet olduğu tespit edilmiştir. [12] tarafından yapılan çalışma ile araştırmamız arasında kısmen benzerlik görülmüştür.

Bin tane ağırlığına çeşitlerin etkisi istatistiki olarak önemli $(\mathrm{p}<0.05)$ bulunurken, farklı sıra aralıklarının ve sıra aralığ1 x çeşit interaksiyonun etkisi önemsiz bulunmuştur (Tablo 4). Bin tane ağırlığı değerleri sıra aralıklarında 7.03-7.51 g arasında değişirken, en yüksek değer $7.51 \mathrm{~g}$ ile $15 \mathrm{~cm}$ sıra aralığından elde edilmiştir. Çeşitlerde ise bin tane ağırlı̆̆ Kara Kız çeşidinde 7.65 g ve Beyaz Gelin çeşidinde 6.83 g olmuştur. Bin tane ağırlığı ortalamasının $7.24 \mathrm{~g}$ olduğu tespit edilmiştir. [4] tarafindan yapılan çalışmaya benzer şekilde farklı sıra aralıklarının bin tane ağırlığı üzerine istatistiki olarak önemli bir etkisi bulunmadığı görülmüştür.

Tablo 4. Bitkideki kapsül sayısı, kapsüldeki tohum sayısı, bin tane ağırlığı, yağ ve protein oranları özelliklerinin ortalama değerleri

\begin{tabular}{|c|c|c|c|c|c|}
\hline & $\begin{array}{l}\text { Bitkideki Kapsül } \\
\text { Sayısı (adet) }\end{array}$ & $\begin{array}{c}\text { Kapsüldeki } \\
\text { Tohum Sayıs1 } \\
\text { (adet) }\end{array}$ & $\begin{array}{l}\text { Bin Tane Ağırlığ } 1 \\
(\mathrm{~g})\end{array}$ & Yağ Oranı $(\%)$ & $\begin{array}{c}\text { Protein Oran } 1 \\
(\%)\end{array}$ \\
\hline \multicolumn{6}{|l|}{ Sira Aralığl } \\
\hline $15 \mathrm{~cm}$ & $16.63 \pm 4.18 b$ & $5.98 \pm 1.09 \mathrm{~b}$ & $7.51 \pm 0.63$ & $33.41 \pm 7.02$ & $19.07 \pm 1.01 \mathrm{c}$ \\
\hline $30 \mathrm{~cm}$ & $38.35 \pm 5.73 \mathrm{a}$ & $6.28 \pm 0.77 \mathrm{~b}$ & $7.15 \pm 0.62$ & $37.48 \pm 0.33$ & $21.03 \pm 0.72 \mathrm{a}$ \\
\hline $45 \mathrm{~cm}$ & $41.85 \pm 8.17 \mathrm{a}$ & $8.33 \pm 1.67 \mathrm{a}$ & $7.03 \pm 0.56$ & $36.73 \pm 0.79$ & $20.13 \pm 1.16 \mathrm{~b}$ \\
\hline $60 \mathrm{~cm}$ & $34.20 \pm 3.46 \mathrm{a}$ & $7.72 \pm 1.40 \mathrm{ab}$ & $7.26 \pm 0.71$ & $36.84 \pm 0.99$ & $19.83 \pm 1.01 \mathrm{~b}$ \\
\hline \multicolumn{6}{|l|}{ Çeşit } \\
\hline $\mathrm{KK}$ & $31.93 \pm 8.85$ & $7.19 \pm 2.05$ & $7.65 \pm 0.35 \mathrm{~A}$ & $35.89 \pm 5.30$ & $20.71 \pm 0.85 \mathrm{~A}$ \\
\hline BG & $33.58 \pm 13.56$ & $6.97 \pm 0.91$ & $6.83 \pm 0.55 \mathrm{~B}$ & $36.34 \pm 0.75$ & $19.32 \pm 1.03 \mathrm{~B}$ \\
\hline Ortalama & $32.76 \pm 11.23$ & $7.08 \pm 1.56$ & $7.24 \pm 0.62$ & $36.11 \pm 3.71$ & $20.01 \pm 1.17$ \\
\hline Sira Aralığ & $* *$ & $*$ & öd & öd & $* *$ \\
\hline Çeşit & öd & öd & $*$ & öd & $* *$ \\
\hline $\mathrm{S} \times \mathrm{C}$ & öd & öd & öd & öd & öd \\
\hline C.V. $(\%)$ & 19.49 & 18.05 & 7.01 & 9.61 & 2.80 \\
\hline
\end{tabular}

$* \mathrm{p}<0.05, * * \mathrm{p}<0.01$ düzeyinde önemlidir. A, B harfleri çeşitler arasındaki ve a, b, c, d harfleri ise sıra aralığı arasındaki fark1 göstermektedir. öd: Önemli değil. CV: Varyasyon katsayısı. KK: Kara Kız, BG: Beyaz Gelin.

Yağ oranına farklı sıra aralıklarının, çeşitlerin ve sıra aralığı x çeşit interaksiyonunun etkisi istatistiki olarak önemsiz ( $\mathrm{p}>0.05$ ) bulunmuştur (Tablo 4). Yağ oranı değerleri sıra aralıklarında \%33.41-37.48 arasında değişirken, en yüksek değer \%37.48 ile $30 \mathrm{~cm}$ sıra aralığından elde edilmiştir. Çeşitlerde ise yă̆ oranı Beyaz Gelin çeşidinde \%36.34 ve Kara Kız çeşidinde \%35.89 olmuştur. Yağ oranı ortalamasının \%36.11 olduğu tespit edilmiştir. Yağ oranları bakımından [4] tarafından bildirilen sonuçlarla paralellik göstermiştir.

Protein oranına farklı sıra aralıklarının ve çeşitlerin etkisi istatistiki olarak önemli $(\mathrm{p}<0.05)$ bulunurken, sıra aralığ1 x çeşit interaksiyonun etkisi önemsiz bulunmuştur (Tablo 4). Protein oranı değerleri sıra aralıklarında \%19.0721.03 arasında değişirken, en yüksek değer \%21.03 ile $30 \mathrm{~cm}$ sıra aralığından elde edilmiştir. Çeşitlerde ise protein 
oranı Kara Kız çeşidinde \%20.71 ve Beyaz Gelin çeşidinde \%19.32 olmuştur. Protein oranı ortalamasının \%20.01 olduğu tespit edilmiştir. Yağ oranına benzer şekilde protein oranında da [4] tarafından bildirilen sonuçlarla benzerlik bulunmuştur.

\section{Sonuçlar ve tartışma}

Yapılan Pearson korelasyon analizi sonucunda elde edilen değerler Tablo 5'te verilmiştir. Tohum verimi ile bitki boyu $(r=0.660)$, teknik sap uzunluğu $(r=0.825)$ ve bitki başına yan dal sayısı $(r=0.549)$ arasında pozitif korelasyon bulunurken, bitkideki kapsül sayısı $(r=-0.465)$ ve kapsüldeki tohum sayısı $(r=-0.470)$ arasında negatif korelasyon tespit edilmiştir. Yağ oranı ile yan dal sayısı arasında negatif korelasyon $(r=-0.519)$ bulunurken, protein oranı ile diğer özellikler arasında istatistiki olarak önemli bir ilişki tespit edilmemiştir. Bitki boyu ile teknik sap uzunluğu arasında yüksek seviyede pozitif korelasyon $(r=0.782)$ bulunmuştur.

Sıra aralığının artışına bağlı olarak teknik sap uzunluğu değerlerinde azalmalar olmuştur. Aksine, meyveli dal sayısında ise sıra aralığının artmasıyla oluşan meyveli dal sayısı da artmıştır. Yan dal sayısının en düşük sıra aralığında $(15 \mathrm{~cm})$ daha fazla oluşmasına paralel şekilde verim de en fazla bu aralıktan elde edilmiş, en yüksek sıra aralığı olan 60 cm'nin neredeyse 3 katı tohum verimi alınmıştır. Sıra aralığının bin tane ağırlığı ve yağ oranına istatistiki olarak bir etkisi bulunmazken, protein oranına etki etmiş ve en yüksek protein oranı $30 \mathrm{~cm}$ sıra aralığından alınmıştır.

$\mathrm{Bu}$ çalışma ile Hatay yöresinde tohum verimi açısından $15 \mathrm{~cm}$ sıra aralığının ve Kara Kız çeşidinin önerilebileceği sonucuna varılmıştır. Ancak, çalışmanın tek yıllık olması ve yörede yapılmış çalışmaların yeterli olmaması nedeniyle kesin bir sonuca varmak mümkün değildir. Bu çalışmanın, yapılacak yeni çalışmalara katkı sunacağ1 düşünülmektedir.

Tablo 5. İncelenen özellikler arasındaki Pearson korelasyon katsayısı değerleri

\begin{tabular}{|c|c|c|c|c|c|c|c|c|c|c|}
\hline & $\mathrm{BB}$ & MDS & $\mathrm{KS}$ & $\mathrm{TS}$ & TSU & YDS & BTA & TV & $\mathrm{PO}$ & YO \\
\hline $\mathrm{BB}$ & 1 & & & & & & & & & \\
\hline MDS & 0.236 & 1 & & & & & & & & \\
\hline $\mathrm{KS}$ & 0.141 & 0.398 & 1 & & & & & & & \\
\hline TS & -0.246 & 0.188 & 0.332 & 1 & & & & & & \\
\hline TSU & 0.782 & 0.023 & -0.225 & -0.475 & 1 & & & & & \\
\hline YDS & 0.237 & -0.089 & -0.442 & -0.171 & 0.560 & 1 & & & & \\
\hline BTA & -0.129 & -0.178 & -0.352 & -0.002 & -0.276 & -0.175 & 1 & & & \\
\hline TV & 0.660 & -0.142 & -0.465 & -0.470 & 0.825 & 0.549 & 0.149 & 1 & & \\
\hline $\mathrm{PO}$ & 0.281 & 0.344 & 0.365 & 0.221 & -0.163 & -0.221 & 0.246 & -0.056 & 1 & \\
\hline YO & 0.114 & 0.025 & 0.372 & 0.403 & -0.393 & -0.519 & 0.194 & -0.280 & 0.355 & 1 \\
\hline
\end{tabular}

Koyu renkli değerler p < 0.01 seviyesinde önemlidir. BB: Bitki boyu, MDS: Bitki başına meyveli dal sayısı, KS: Bitkideki kapsül sayıs1, TS: Kapsüldeki tohum sayısı, TSU: Teknik sap uzunluğu, YDS: Bitki başına yan dal sayısı, BTA: Bin tane ağırlı̆̆, TV: Tohum verimi, PO: Protein oranı, YO: Yağ oranı.

\section{Teşekkür}

$\mathrm{Bu}$ çalışma, Ayşe ÇOBAN'ın yüksek lisans tezinin bir bölümünden türetilmiştir. Tohum temininde yardımlarını esirgemeyen Dr. Metin BABAOĞLU'na teşekkür ediyoruz.

\section{Kaynaklar}

[1] Tunçtürk, M. (2007). Van Koşullarında Bazı Keten (Linum usitatissimum L.) Çeşitlerinin Verim ve Bazı Verim Ögelerinin Belirlenmesi. Tarım Bilimleri Dergisi, 13(4), 365-371.

[2] Mert, M. (2009). Lif Bitkileri. Ankara: Nobel Yayın Dağıtım.

[3] Sargın, S.A., Selvi, S. \& Erdoğan, E. (2013). Alaşehir (Manisa) yöresindeki aktarlarda satılan tıbbi bitkiler ve kullanım özellikleri. Biological Diversity and Conservation, 6(3), 40-45.

[4] Çöl Keskin, N., Öztürk, Ö., Endes Eğribaş, Z. \& Yılmaz, E. (2020). Bazı Yağlık Keten Çeşitlerinde Farklı Sıra Aralıklarının Verim ve Verim Unsurları Üzerine Etkilerinin Belirlenmesi. Ziraat Fakültesi Dergisi, Türkiye 13. Ulusal, I. Uluslararası Tarla Bitkileri Kongresi Özel Sayısı:109-120.

[5] FAOSTAT. (2021). Food and agriculture data. Retrieved from http://www.fao.org/faostat/en/\#home

[6] TÜİK. (2021). Bitkisel üretim istatistikleri. Retrieved from https://biruni.tuik.gov.tr/medas/ 
[7] Kurt, O., Uysal, H., Demir, A. \& Göre, M. (2015). Samsun ekolojik koşullarında geliştirilen bazı keten (Linum usitatissimum L.) hatlarının tarımsal özelliklerinin belirlenmesi. Anadolu Tarım Bilimleri Dergisi, 30(2), $136-140$. https://doi: 10.7161/anajas.2015.30.2.136-140

[8] Örs, Ö. \& Öztürk, Ö. (2018). Konya Koşullarında Yağlık Keten (Linum usitatissimum L.) Çeşitlerinin Verim ve Bazı Tarımsal Özelliklerinin Belirlenmesi. Selçuk Tarım ve Gıda Bilimleri Dergisi, 32(3), 305-311. https://doi: 10.15316/SJAFS.2018.98

[9] Yılmaz, G., Telci, İ., Kandemir, N. \& Özdamar, M. (2007). Bazı keten çeşitlerinin Tokat koşullarındaki performansları. Paper presented at the 1. Ulusal Yağlı Tohumlu Bitkiler ve Biyodizel, Samsun.

[10] Bozkurt, D. \& Kurt, O. (2007). Keten (Linum usitatissimum L.)'in verim ve verim unsurlarına ekim zamanı ve toprak sıcaklığının etkisi, Anadolu Tarim Bilimleri Dergisi, 22(1), 20-25.

[11] Karaaslan, D. \& Tonçer, Ö. (2001). Diyarbakır koşullarında bazı keten çeşitlerinin adaptasyon üzerine bir araştırma. Paper presented at the Türkiye 4. Tarla Bitkileri Kongresi, Tekirdağ.

[12] Yıldırım, M. \& Arslan, N. (2013). Seçilmiş keten (Linum usitatissimum L.) hatlarının bazı bitkisel özelliklerinin karşılaştırılması, Tarla Bitkileri Merkez Araştırma Enstitüsü Dergisi, 22(2), 59-68.

[13] Endes, Z. \& Akınerdem, F. (2011). Konya şartlarında bazı yağlık keten (Linum usitatissimum L.) çeşit ve populasyonlarında farklı ekim zamanlarının verim üzerine etkisinin belirlenmesi, Selçuk Tarım Bilimleri Dergisi, 25(2), 30-38.

[14] Kurt, O., Doğan, H. \& Demir, A. (2006). Samsun ekolojik koşullarına uygun kışlık keten çeşitlerinin belirlenmesi üzerinde bir araştırma, OMÜ Zir. Fak. Dergisi, 21(1), 1-5. 